\title{
THE EFFECT OF ROCK PHOSPHATE ON SOIL NUTRIENT DYNAM- ICS, GROWTH, DEVELOPMENT AND YIELD OF OIL PALM IN THE SEMI-DECIDUOUS FOREST ZONE OF GHANA
}

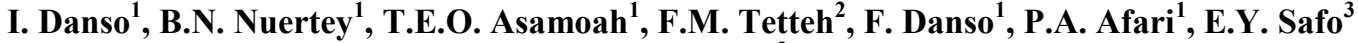 \\ and V. Logah ${ }^{3}$ \\ ${ }^{1}$ CSIR-Oil Palm Research Institute, Box 74, Kade \\ ${ }^{2}$ Soil Research Institute, CSIR, Academy Post Office, Kumasi. \\ ${ }^{3}$ Department of crops and Soil science, Kwame Nkrumah University of Science and Technology, Kumasi
}

\begin{abstract}
Field experiment was conducted at Oil Palm Research Institute, Kusi from 2002 to 2007 to assess the effect of Phosphate Rock (PR) on soil nutrient dynamics, growth, development and yield of oil palm. The study was carried out on the soils of Nzema series classified as Ferric Acrisols and Typic Hapludult. The oil palm trees selected were 8 year old tenera (DXP ex OPRI). Each plot measured $17.6 \mathrm{~m} \times 17.6 \mathrm{~m}$ and had 6 palm trees. There were four treatments arranged in randomized complete block design with four replicates. The treatments included: 1). TSP - OPRI fertilizer recommendation - $222 \mathrm{~kg}$ of $A S+222 \mathrm{~kg}$ of TSP + $296 \mathrm{~kg}$ of MOP/ha/yr (control); 2). $P R 1-P R 715 \mathrm{~kg}+222 \mathrm{~kg}$ of AS +296 kg of MOP/ha $-\mathrm{Yr} 1 . P R 358 \mathrm{~kg}+222 \mathrm{~kg}$ of AS + $296 \mathrm{~kg}$ of MOP/ ha - Yr 2. PR $358 \mathrm{~kg}+222 \mathrm{~kg}$ of AS + $296 \mathrm{~kg}$ of MOP/ha - Yr 3; 3). PR2 - PR $1428 \mathrm{~kg}$ $+222 \mathrm{~kg}$ of AS + $296 \mathrm{~kg}$ of MOP/ha applied once in every 5 years; 4). PR3 - PR $142.85 \mathrm{~kg} / \mathrm{ha}$ $+222 \mathrm{~kg} \mathrm{AS} / \mathrm{ha}+296 \mathrm{~kg}$ of MOP/ha applied twice in every 5 years. Application of treatments influenced the soil chemical properties to a varying extent. Gradual increase in soil nutrient levels were more pronounced in RP treatments than Triple Super Phosphate (TSP) treatment (control). Soil pH increased from extremely acidic (3.73) to acidic (5.43) for treatment PR2. At the end of the study, available $P$ recorded $9.55 \mathrm{mg} / \mathrm{kg}$. The value is slightly below the medium range of available $P$ for oil palm production. Significant increases were recorded by $R P$ treatments for exchangeable $\mathrm{Ca}, \mathrm{Mg}, \mathrm{K}$ and $\mathrm{ECEC}$. The results showed that treatment $P R 2$ was effective and gave the highest oil palm yield of $62.8 t /$ ha with TSP recording $53.7 t /$ ha. For sustained levels of soil nutrients, growth, development and yield of oil palm, PR incorporation should be encouraged.
\end{abstract}

Keywords: Phosphate Rock, nutrient dynamics, oil palm, triple super phosphate

\section{INTRODUCTION}

With the current increase in cost of oil palm production subsequent reduction in farmer's income, there is the need to search for low input farming strategies such the use of Togo
Phosphate Rock (TPR) with about 25.5\% $\mathrm{P}_{2} \mathrm{O}_{5}$ (CSIR-OPRI Annual Report, 2007). This may reduce cost of oil palm production and improve the incomes of oil palm stakeholders, especially the small scale oil palm farmers. Some studies 
have shown poor soil fertility status of most soils under oil palm production. At Bogoso in the Western region, Tetteh and Dedzoe (2004) and Tetteh et al., (2002) evaluated the soil fertility levels of some benchmark soils under oil palm, cocoa and maize. According to the authors, soil fertility levels of most of the soils were very low. Most of the soils were found to be acidic $(\mathrm{pH}<5.0)$, low in available $\mathrm{P}$ and exchangeable cations. Similar studies at Bawjiase in the Central Region also revealed similar results regarding soil fertility status (Dedzoe et al., 2004). Studies carried out by Asamoah and Nuertey (2005) also revealed that areas climatically suitable for optimal oil palm production in Ghana have limitations including poor drainage, hazards of erosion, high acidity and low nutrients.

Phosphate Rock (PR) is a raw material that contains phosphate mineral for making superphosphate fertilizers. It can be utilized as direct application fertilizer in acid soils because of the low input cost and slow release of $P$ to the soil (Sale and Mokwunye, 1993). In Brazil a single application of PR per ha of land deficient of $\mathrm{P}$ gave 100 percent yield increase in oil palm over a period of 6 years (Hartley, 1988). This agrees with the role PR play in increasing yield (ton / ha) by 58 percent of oil palm in Indonesia in a second year following implementation of best management practices (Griffiths and Fairhust, 2002). According to Zin et al., (2005) PR fertilizers have a higher content of calcium ranging from $24-33 \%$. This makes PR beneficial in increasing soil $\mathrm{pH}$ and cation exchange capacity (CEC) resulting in yield increases of oil palm. Foster et al., (1998) noted that the effects of direct application of PR in mature oil palm under Malaysia soil conditions have been very promising. Similarly, in phosphorus deficient soils of Brazil as pertains in tropical Africa, a large initial application of PR had a superior effect to annual doses of triple superphosphate (IRHO, 1974). Its incorporation ensures a steady supply of $\mathrm{P}$ over a long period and also provides a high rooting density to crops (Bolan et al., 1990).
Therefore the objective of this work is to conduct a detailed study to examine the effect of PR on soil nutrient dynamics, growth, development and yield of oil palm.

\section{MATERIALS AND METHODS}

Site description and experimental design

A field experiment was conducted between 2002 to 2007 at the Oil Palm Research Institute (OPRI), Kusi in the semi-deciduous forest zone of Ghana. The study was carried out on the soils of Nzema series classified as Ferric Acrisols (FAO, 1990) and Typic Hapludult (USDA, 1991). The area is in a zone characterized by relatively high rainfall, which falls in two seasons. The major rainy season occurs from April to July. The minor rainy season begins in September to the end of October/or mid November. Average annual rainfall is about $1425 \mathrm{~mm}$. The oil palm trees selected were 8 year old tenera (DXP ex OPRI). Each plot measured $17.6 \mathrm{~m} \times 17.6 \mathrm{~m}$ and had 6 oil palms trees. There were four treatments, consisting of: 1).Triple Super Phosphate - OPRI fertilizer recommendation - $222 \mathrm{~kg}$ of ammonium sulphate $+222 \mathrm{~kg}$ of triple super phosphate +296 $\mathrm{kg}$ of muriate of potash/ha/yr (control); 2). PR1 - PR $715 \mathrm{~kg}+222 \mathrm{~kg}$ of ammonium sulphate + $296 \mathrm{~kg}$ of muriate of potash/ha - Yr 1. PR 358 $\mathrm{kg}+222 \mathrm{~kg}$ of ammonium sulphate $+296 \mathrm{~kg}$ of muriate of potash $/$ ha - Yr 2. PR $358 \mathrm{~kg}+222$ $\mathrm{kg}$ of ammonium sulphate $+296 \mathrm{~kg}$ of muriate of potash/ha -Yr 3; 3). PR2 - PR $1428 \mathrm{~kg}+222$ $\mathrm{kg}$ of ammonium sulphate $+296 \mathrm{~kg}$ of muriate of potash/ha applied once in every 5 years; 4 ). PR3 - PR $142.85 \mathrm{~kg} / \mathrm{ha}+222 \mathrm{~kg}$ ammonium sulphate $/ \mathrm{ha}+296 \mathrm{~kg}$ of muriate of potash / ha applied twice in every 5 years. The experimental design was randomized complete block with 3 replicates. Treatment plots were broadcast with appropriate straight fertilizers individually within the interrows and rings of palm trees ( $1.5 \mathrm{~m}$ radius around the palm).

\section{Laboratory analysis}

Composite soil samples (0-15 cm and 15-30 cm soil depth) were taken from experimental field before treatment application and subsequently 


\section{Danso et al.}

annually from each plot. The composite soil samples were air dried for 24 hours and then sieved with a mesh of $2 \mathrm{~mm}$ diameters for chemical analysis. Soil $\mathrm{pH}$ was measured with 1:2.5 soil:water suspension using a HI 9017 microprocessor $\mathrm{pH}$ meter. The Walkley and Black procedure as modified by Nelson and Sommers (1982) was used to assess the organic $\mathrm{C}$ content in the soils. Total $\mathrm{N}$ was determined by Kjeldahl digestion method. The available $\mathrm{P}$ was extracted with a $\mathrm{HCl}: \mathrm{NH}_{4} \mathrm{~F}$ mixture method as described by Bray and Kurtz (1945) and determined colorimetrically using the molybdenum blue method at the wavelength using the molybdenum blue method at the wavelength of $636 \mathrm{~nm}$. Exchangeable bases (calcium, magnesium, potassium and sodium) in the soil were determined in $1.0 \mathrm{M}$ ammonium acetate extract and exchangeable acidity (hydrogen and aluminium) was determined in $1.0 \mathrm{M} \mathrm{KCl} \mathrm{ex-}$ tract. The Effective Cation Exchange Capacity (ECEC) was calculated as the sum of ex- changeable bases and exchangeable acidity (Table 1). Soil particle size was determined by using the hydrometer method (Bouyoucos, 1962).

\section{Statistical analysis}

All data obtained, were subjected to analysis of variance (ANOVA) using Genstat statistical package (Genstat, 1997). Separation of means was done using the least significant difference at $\mathrm{P}=0.05$

\section{RESULTS}

Pre-experimental soil characteristics

Some physical and chemical properties of the soil at the experimental site before imposition of treatments are presented in Table 1. The soil $\mathrm{pH}$ was extremely acidic at both depths. Effective cation exchange capacity (ECEC), total nitrogen, organic matter content and exchangeable potassium were low and the level of available phosphorus was below the deficiency

Table 1: Chemical and physical properties of soil at experimental site before application of treatments

\begin{tabular}{lcl}
\hline Soil Property & $0-15$ & Soil Depth (cm) \\
\hline pH $\left(1: 2.5 \mathrm{H}_{2} \mathrm{O}\right)$ & 4.42 & $15-30$ \\
Org. Carbon (\%) & 1.05 & 4.13 \\
Organic matter $(\%)$ & 1.81 & 0.56 \\
Total N (\%) & 0.11 & 0.97 \\
Avail. Bray's (mg/kg) & & 0.05 \\
$\mathrm{P}$ & 0.80 & \\
$\mathrm{~K}$ & 69.20 & 0.20 \\
& & 131.30 \\
Exchangeable bases (cmol/kg) & & \\
Ca & 2.88 & 1.44 \\
$\mathrm{Mg}$ & 1.60 & 0.64 \\
$\mathrm{~K}$ & 0.06 & 0.07 \\
Na & 0.08 & 0.15 \\
TEB & 4.62 & 2.30 \\
Exhangeable acidity (cmol/kg) & 0.25 & 1.05 \\
ECEC (cmol/kg) & 4.87 & 3.35 \\
Base saturation $(\%)$ & 94.90 & 68.70 \\
Particle size $(\%)$ & & \\
Sand & 68.00 & 60.00 \\
Silt & 27.00 & 32.00 \\
Clay & 5.00 & 8.00 \\
Texture & Sandy loam & Sandy loam \\
\hline
\end{tabular}

Journal of Science and Technology @ KNUST April 2010 
threshold of $10 \mathrm{mg} / \mathrm{kg}$ (Hartley, 1988) for plants. Exchangeable $\mathrm{Ca}$ and $\mathrm{Mg}$ values were below the critical values of 5.0 and $1.0 \mathrm{cmol} / \mathrm{kg}$ respectively, in both depths (Healed, 1965). Generally, the fertility of the soil was low and decreased with depth and crop response to the major nutrients especially $\mathrm{P}$ was expected.

From the results of particle size analysis, the content of sand, clay and silt were 68,27 and $5 \%$ for $0-15 \mathrm{~cm}$ soil depths and 60,32 and $8 \%$ for sand, clay and silt respectively. Hence, the soil was classified as sandy loam in both depths.

\section{Effect of treatments on soil pH}

The effect of treatments on soil $\mathrm{pH}$ is shown in Table 2. Differences that were recorded during the test period were significant in 2004 and 2007 for both soil depths and 2006 in $0-15 \mathrm{~cm}$ soil depth only. Values of $\mathrm{pH}$ increased gradually from 2004 to 2007 for PR treatments in both soil depths. Soil $\mathrm{pH}$ values for the control (TSP) in the $0-15 \mathrm{~cm}$ soil depth gradually decreased from 2004 to 2006 but eventually increased by 0.87 units from 2006 to 2007 . Soil $\mathrm{pH}$ values for control (TSP) in $15-30 \mathrm{~cm}$ soil depth remained constant (4.22) from 2004 to 2006. However, there was an increase of 0.51 units from 2006 to 2007 in soil depth $15-30 \mathrm{~cm}$.

\section{Effect of treatment on soil organic matter}

Table 3 shows organic matter content of the soil as affected by treatments. Changes in organic matter content over the test period were not significantly influenced in both soil depths. Significant difference was rather observed among the treatments in 2004 at $15-30 \mathrm{~cm}$ soil depth. Organic matter levels were moderate to high and ranged from 1.56 to $5.33 \%$ in the 0 $15 \mathrm{~cm}$. These values decreased with soil depth. A gradual increase in organic matter content from 2004 to 2007 during the period was recorded. However, from 2006 to 2007 in the PR2 treatments, both soil depths experienced organic matter reduction by $4.00 \%$ and 15.00 $\%$ for $0-15 \mathrm{~cm}$ and $15-30 \mathrm{~cm}$, respectively.

\section{Effect of treatment on total soil nitrogen}

Total soil nitrogen values showed no significant difference among treatments for both soil depths (Table 4). Comparatively, total $\mathrm{N}$ values in 2004 were lower than 2007 values.

Increase in total N values in 2007 over 2004 were 28.0 and $51.0 \%$ for $0-15 \mathrm{~cm}$ and $15-30$ $\mathrm{cm}$ soil depths respectively. Values recorded in 2005 and 2006 for PR2 treatment in $0-15 \mathrm{~cm}$

Table 2: Effect of treatment on dynamics of soil pH from 2004 to 2007

\begin{tabular}{lcrrr}
\hline Treatment & $\mathbf{2 0 0 4}$ & $\mathbf{2 0 0 5}$ & $\mathbf{2 0 0 6}$ & \multicolumn{2}{c}{$\mathbf{2 0 0 7}$} \\
\hline & \multicolumn{1}{c}{$\mathbf{0 - 1 5} \mathbf{~ c m}$ soil depth } & & \\
TSP & $4.27 \mathrm{a}$ & $4.12 \mathrm{a}$ & $3.99 \mathrm{~b}$ & $4.86 \mathrm{bc}$ \\
PR1 & $4.22 \mathrm{a}$ & $4.32 \mathrm{a}$ & $4.43 \mathrm{ab}$ & $5.08 \mathrm{a}$ \\
PR2 & $3.76 \mathrm{~b}$ & $4.42 \mathrm{a}$ & $5.09 \mathrm{a}$ & $5.37 \mathrm{a}$ \\
PR3 & $4.11 \mathrm{a}$ & $4.33 \mathrm{a}$ & $4.65 \mathrm{ab}$ & $4.72 \mathrm{c}$ \\
CV (\%) & 5.9 & 5.6 & 9.8 & 3.4 \\
LSD (5\%) & 0.48 & 0.47 & 0.88 & 0.34 \\
& $\mathbf{1 5}-\mathbf{3 0}$ cm soil depth & & \\
TSP & $4.22 \mathrm{a}$ & $4.22 \mathrm{a}$ & $4.22 \mathrm{a}$ & $4.73 \mathrm{~b}$ \\
PR1 & $4.10 \mathrm{a}$ & $4.49 \mathrm{a}$ & $4.88 \mathrm{a}$ & $5.09 \mathrm{ab}$ \\
PR2 & $4.13 \mathrm{a}$ & $4.66 \mathrm{a}$ & $5.18 \mathrm{a}$ & $5.39 \mathrm{a}$ \\
PR3 & $3.76 \mathrm{~b}$ & $4.30 \mathrm{a}$ & $4.85 \mathrm{a}$ & $5.43 \mathrm{a}$ \\
CV (\%) & 4.1 & 9.8 & 15.6 & 3.9 \\
LSD (5\%) & 0.32 & 0.86 & 1.49 & 0.39 \\
\hline
\end{tabular}

Means followed by the same letter are not significantly different $(P>0.05)$. 


\section{Danso et al.}

soil depth had the highest total $\mathrm{N}$ values and these were higher than the critical soil nutrient value of $0.2 \%$ (Hartley, 1988). However, by 2007 PR2 treatment in soil depth $0-15 \mathrm{~cm}$ had dropped by $20.0 \%$.

Effect of treatment on available phosphorus Table 5 shows the available phosphorus levels as influenced by treatments. Differences that were recorded during the period were not significant in both soil depths. Available phosphorus values increased gradually from 2004 to 2006. However, from 2006 to 2007 there was a drop in available phosphorus values for treatments TSP (control) in $0-15 \mathrm{~cm}, \mathrm{PR} 1$ in $0-15$ $\mathrm{cm}$ and TSP (control) in 15-30 cm soil depth. The respective drops were 26.0, 31.6 and 6.5

Table 3: Effect of treatment on dynamics of soil organic matter (\%) from 2004 to 2007

\begin{tabular}{lcccc}
\hline Treatment & $\mathbf{2 0 0 4}$ & $\mathbf{2 0 0 5}$ & $\mathbf{2 0 0 6}$ & $\mathbf{2 0 0 7}$ \\
\hline \multicolumn{4}{c}{$\mathbf{0 - 1 5} \mathbf{~ c m ~ s o i l ~ d e p t h ~}$} \\
TSP & $1.8 \mathrm{a}$ & $2.07 \mathrm{a}$ & $2.33 \mathrm{a}$ & $2.96 \mathrm{a}$ \\
PR1 & $1.78 \mathrm{a}$ & $2.07 \mathrm{a}$ & $2.30 \mathrm{a}$ & $3.12 \mathrm{a}$ \\
PR2 & $1.75 \mathrm{a}$ & $3.54 \mathrm{a}$ & $5.33 \mathrm{a}$ & $2.74 \mathrm{a}$ \\
PR3 & $1.56 \mathrm{a}$ & $2.13 \mathrm{a}$ & $2.70 \mathrm{a}$ & $3.25 \mathrm{a}$ \\
CV (\%) & 10.9 & 2.85 & 87.1 & 27.90 \\
LSD (5\%) & 0.37 & 58.50 & 5.50 & 1.68 \\
TSP & $\mathbf{1 5}-\mathbf{3 0} \mathbf{~ c m ~ s o i l ~ d e p t h ~}$ & & \\
PR1 & $1.05 \mathrm{a}$ & $1.25 \mathrm{a}$ & $1.45 \mathrm{a}$ & $1.90 \mathrm{a}$ \\
PR2 & $0.92 \mathrm{ab}$ & $1.05 \mathrm{a}$ & $1.18 \mathrm{a}$ & $2.05 \mathrm{a}$ \\
PR3 & $0.70 \mathrm{~b}$ & $1.37 \mathrm{a}$ & $2.06 \mathrm{a}$ & $1.75 \mathrm{a}$ \\
CV (\%) & $0.94 \mathrm{a}$ & $0.99 \mathrm{a}$ & $1.05 \mathrm{a}$ & $1.84 \mathrm{a}$ \\
LSD (5\%) & 13.40 & 45.8 & 77.60 & 20.50 \\
\hline
\end{tabular}

Means followed by the same letter are not significantly different $(P>0.05)$

Table 4: Effect of treatment on dynamics of total nitrogen (\%) from 2004 to 2007

\begin{tabular}{lcccc}
\hline Treatment & $\mathbf{2 0 0 4}$ & $\mathbf{2 0 0 5}$ & $\mathbf{2 0 0 6}$ & $\mathbf{2 0 0 7}$ \\
\hline \multicolumn{5}{c}{$\mathbf{0 - 1 5} \mathbf{~ c m}$ soil depth } \\
TSP & $0.10 \mathrm{a}$ & $0.11 \mathrm{a}$ & $0.11 \mathrm{a}$ & $0.15 \mathrm{a}$ \\
PR1 & $0.11 \mathrm{a}$ & $0.11 \mathrm{a}$ & $0.11 \mathrm{a}$ & $0.15 \mathrm{a}$ \\
PR2 & $0.10 \mathrm{a}$ & $0.22 \mathrm{a}$ & $0.27 \mathrm{a}$ & $0.13 \mathrm{a}$ \\
PR3 & $0.11 \mathrm{a}$ & $0.12 \mathrm{a}$ & $0.13 \mathrm{a}$ & $0.16 \mathrm{a}$ \\
CV (\%) & 6.80 & 66.00 & 90.00 & 30.20 \\
LSD (5\%) & 0.01 & 0.18 & 0.28 & 0.09 \\
& $\mathbf{1 5 - 3 0} \mathbf{~ c m ~ s o i l ~ d e p t h ~}$ & & \\
TSP & $0.04 \mathrm{a}$ & $0.06 \mathrm{a}$ & $0.07 \mathrm{a}$ & $0.10 \mathrm{a}$ \\
PR1 & $0.05 \mathrm{a}$ & $0.17 \mathrm{a}$ & $0.04 \mathrm{a}$ & $0.10 \mathrm{a}$ \\
PR2 & $0.02 \mathrm{a}$ & $0.06 \mathrm{a}$ & $0.10 \mathrm{a}$ & $0.08 \mathrm{a}$ \\
PR3 & $0.03 \mathrm{a}$ & $0.04 \mathrm{a}$ & $0.05 \mathrm{a}$ & $0.01 \mathrm{a}$ \\
CV (\%) & 40.70 & 132.60 & 45.70 & 25.80 \\
LSD (5\%) & 0.03 & 0.22 & 0.10 & 0.05 \\
\hline
\end{tabular}

Means followed by same letter are not significantly different $(P>0.05)$

Journal of Science and Technology ㄷN KNUST April 2010 
$\%$. Generally, available phosphorus values decreased with depth.

Effect of treatment on available potassium Available potassium as influenced by treatments is shown in Table 6 . There was a gradual increase in available potassium from 2004 to 2007 for all treatments in both depths. Available potassium values were generally low to high and ranged from 31.50 to $121.60 \mathrm{mg} / \mathrm{kg}$ and 19.50 to $125.6 \mathrm{mg} / \mathrm{kg}$ in the $0-15 \mathrm{~cm}$ and
15-30 $\mathrm{cm}$ depths respectively. However, increased values from 2006 to 2007 were more pronounced. Treatment differences that were recorded during the test period were not significant in both soil depths.

Effect of treatment on exchangeable calcium Table 7 shows the effect of treatments on the dynamics of exchangeable calcium. Values of exchangeable calcium increased from 2004 to 2007. However, from 2006 to 2007 a drop in in

Table 5: Effect of treatment on dynamics of available phosphorus (mg/kg) from 2004 to 2007

\begin{tabular}{lcrrr}
\hline Treatment & $\mathbf{2 0 0 4}$ & $\mathbf{2 0 0 5}$ & $\mathbf{2 0 0 6}$ & $\mathbf{2 0 0 7}$ \\
\hline & $\mathbf{0 - 1 5} \mathbf{~ c m}$ soil depth & & \\
TSP & $0.36 \mathrm{a}$ & $2.97 \mathrm{a}$ & $5.60 \mathrm{a}$ & $4.14 \mathrm{a}$ \\
PR1 & $0.41 \mathrm{a}$ & $4.63 \mathrm{a}$ & $8.85 \mathrm{a}$ & $6.05 \mathrm{a}$ \\
PR2 & $0.50 \mathrm{a}$ & $5.59 \mathrm{a}$ & $9.50 \mathrm{a}$ & $9.32 \mathrm{a}$ \\
PR3 & $0.43 \mathrm{a}$ & $2.93 \mathrm{a}$ & $5.44 \mathrm{a}$ & $5.70 \mathrm{a}$ \\
CV (\%) & 35.30 & 40.50 & 42.60 & 47.20 \\
LSD (5\%) & 0.30 & 3.25 & 6.50 & 5.94 \\
& $\mathbf{1 5}-\mathbf{3 0} \mathbf{~ c m}$ soil depth & & \\
TSP & $1.07 \mathrm{a}$ & $1.99 \mathrm{a}$ & $2.91 \mathrm{a}$ & $2.72 \mathrm{a}$ \\
PR1 & $0.33 \mathrm{a}$ & $1.53 \mathrm{a}$ & $2.74 \mathrm{a}$ & $4.43 \mathrm{a}$ \\
PR2 & $0.48 \mathrm{a}$ & $1.54 \mathrm{a}$ & $2.60 \mathrm{a}$ & $4.46 \mathrm{a}$ \\
PR3 & $0.36 \mathrm{a}$ & $1.37 \mathrm{a}$ & $2.38 \mathrm{a}$ & $4.05 \mathrm{a}$ \\
CV (\%) & 74.90 & 42.30 & 51.20 & 46.20 \\
LSD (5\%) & 0.84 & 1.35 & 2.71 & 3.61 \\
\hline
\end{tabular}

Means followed by same letter are not significantly different $(P>0.05)$

Table 6: Effect of treatment on dynamics of available potassium (mg/kg) from 2004 to 2007

\begin{tabular}{lccrr}
\hline Treatment & $\mathbf{2 0 0 4}$ & $\mathbf{2 0 0 5}$ & $\mathbf{2 0 0 6}$ & $\mathbf{2 0 0 7}$ \\
\hline \multicolumn{5}{c}{$\mathbf{0 - 1 5} \mathbf{c m}$ soil depth } \\
TSP & $31.50 \mathrm{a}$ & $33.60 \mathrm{a}$ & $35.80 \mathrm{a}$ & $94.90 \mathrm{a}$ \\
PR1 & $39.90 \mathrm{a}$ & $41.50 \mathrm{a}$ & $43.10 \mathrm{a}$ & $108.2 \mathrm{a}$ \\
PR2 & $37.40 \mathrm{a}$ & $39.90 \mathrm{a}$ & $42.30 \mathrm{a}$ & $68.60 \mathrm{a}$ \\
PR3 & $35.80 \mathrm{a}$ & $37.20 \mathrm{a}$ & $38.40 \mathrm{a}$ & $121.60 \mathrm{a}$ \\
CV (\%) & 20.40 & 23.80 & 28.20 & 27.10 \\
LSD (5\%) & 14.72 & 18.06 & 22.47 & 53.10 \\
TSP & $\mathbf{1 5}-\mathbf{3 0} \mathbf{~ c m ~ s o i l ~ d e p t h ~}$ & & \\
PR1 & $41.30 \mathrm{a}$ & $38.90 \mathrm{a}$ & $36.50 \mathrm{a}$ & $111.60 \mathrm{a}$ \\
PR2 & $22.20 \mathrm{a}$ & $24.60 \mathrm{a}$ & $27.00 \mathrm{a}$ & $93.70 \mathrm{~b}$ \\
PR3 & $22.70 \mathrm{a}$ & $25.40 \mathrm{a}$ & $28.10 \mathrm{a}$ & $125.6 \mathrm{a}$ \\
CV (\%) & $19.50 \mathrm{a}$ & $19.90 \mathrm{a}$ & $20.30 \mathrm{a}$ & $93.70 \mathrm{~b}$ \\
LSD (5\%) & 43.00 & 29.60 & 19.90 & 26.60 \\
\hline
\end{tabular}

Means followed by same letter are not significantly different $(P>0.05)$ 


\section{Danso et al.}

values were recorded in treatments PR2 and PR3 in both soil depths. The drop from 2006 to 2007 in $0-15 \mathrm{~cm}$ soil depth for treatments PR2 and PR3 were $58.1 \%$ and $33.0 \%$ respectively. The drop in exchangeable calcium from 2006 to 2007 in $15-30 \mathrm{~cm}$ soil depth was about $38 \%$ and $39 \%$ for treatments PR2 and PR3 respectively.
Effect of treatment on exchangeable magnesium

Exchangeable magnesium as influenced by treatments is shown in (Table 8) for $0-15 \mathrm{~cm}$ and $15-30 \mathrm{~cm}$ depth respectively. Values increased gradually from 2004 to 2007 in $0-15$ cm depth for TSP and PR1. Treatments PR2 and PR3 dropped from 2006 to 2007 by 1.1 and

Table 7: Effect of treatment on dynamics of soil exchangeable calcium (cmol/kg) from 2004 to 2007

\begin{tabular}{lccrr}
\hline Treatment & $\mathbf{2 0 0 4}$ & $\mathbf{2 0 0 5}$ & $\mathbf{2 0 0 6}$ & $\mathbf{2 0 0 7}$ \\
\hline \multicolumn{5}{c}{$\mathbf{0 - 1 5} \mathbf{~ c m}$ soil depth } \\
TSP & $2.37 \mathrm{a}$ & $2.63 \mathrm{a}$ & $2.90 \mathrm{a}$ & $2.90 \mathrm{a}$ \\
PR1 & $1.70 \mathrm{a}$ & $2.36 \mathrm{a}$ & $3.00 \mathrm{a}$ & $3.84 \mathrm{a}$ \\
PR2 & $3.32 \mathrm{a}$ & $6.68 \mathrm{a}$ & $10.10 \mathrm{a}$ & $4.23 \mathrm{a}$ \\
PR3 & $2.33 \mathrm{a}$ & $3.19 \mathrm{a}$ & $4.00 \mathrm{a}$ & $2.68 \mathrm{a}$ \\
CV (\%) & 34.70 & 77.2 & 100.03 & 38.9 \\
LSD (5\%) & 1.68 & 5.73 & 10.03 & 2.16 \\
& $\mathbf{1 5 - 3 0}$ cm soil depth & & \\
TSP & $2.27 \mathrm{ab}$ & $2.22 \mathrm{a}$ & $2.1 \mathrm{a}$ & $2.89 \mathrm{a}$ \\
PR1 & $1.57 \mathrm{~b}$ & $1.81 \mathrm{a}$ & $2.05 \mathrm{a}$ & $2.76 \mathrm{a}$ \\
PR2 & $3.38 \mathrm{a}$ & $4.32 \mathrm{a}$ & $5.25 \mathrm{a}$ & $3.25 \mathrm{a}$ \\
PR3 & $2.04 \mathrm{ab}$ & $2.64 \mathrm{a}$ & $3.25 \mathrm{a}$ & $1.96 \mathrm{a}$ \\
CV (\%) & 28.90 & 47.10 & 61.60 & 37.40 \\
LSD (5\%) & 1.33 & 2.58 & 3.91 & 2.03 \\
\hline
\end{tabular}

Means followed by same letter are not significantly different $(P>0.05)$.

Table 8: Effect of treatment on dynamics of soil exchangeable magnesium (cmol/kg) from 2004 to 2007

\begin{tabular}{lllll}
\hline Treatment & $\mathbf{2 0 0 4}$ & $\mathbf{2 0 0 5}$ & $\mathbf{2 0 0 6}$ & $\mathbf{2 0 0 7}$ \\
\hline \multicolumn{5}{c}{$\mathbf{0 - 1 5} \mathbf{~ c m ~ s o i l ~ d e p t h ~}$} \\
TSP & $0.74 \mathrm{a}$ & $0.59 \mathrm{a}$ & $0.44 \mathrm{a}$ & $0.93 \mathrm{a}$ \\
PR1 & $0.70 \mathrm{a}$ & $0.82 \mathrm{a}$ & $0.93 \mathrm{a}$ & $1.15 \mathrm{a}$ \\
PR2 & $1.21 \mathrm{a}$ & $1.63 \mathrm{a}$ & $2.05 \mathrm{a}$ & $0.98 \mathrm{a}$ \\
PR3 & $0.99 \mathrm{a}$ & $1.35 \mathrm{a}$ & $1.74 \mathrm{a}$ & $0.93 \mathrm{a}$ \\
CV (\%) & 84.90 & 18.70 & 89.20 & 56.30 \\
LSD (5\%) & 1.54 & 1.87 & 2.30 & 1.12 \\
& $\mathbf{1 5}-\mathbf{3 0} \mathbf{~ c m ~ s o i l ~ d e p t h ~}$ & & \\
TSP & $0.35 \mathrm{a}$ & $0.46 \mathrm{a}$ & $0.58 \mathrm{a}$ & $0.71 \mathrm{a}$ \\
PR1 & $0.35 \mathrm{a}$ & $0.80 \mathrm{a}$ & $1.24 \mathrm{a}$ & $1.07 \mathrm{a}$ \\
PR2 & $0.32 \mathrm{a}$ & $1.36 \mathrm{a}$ & $1.40 \mathrm{a}$ & $2.36 \mathrm{a}$ \\
PR3 & $0.41 \mathrm{a}$ & $1.23 \mathrm{a}$ & $2.04 \mathrm{a}$ & $0.76 \mathrm{a}$ \\
CV (\%) & 53.60 & 72.90 & 88.00 & 96.00 \\
LSD (5\%) & 0.38 & 1.40 & 2.78 & 2.35 \\
\hline
\end{tabular}

Means followed by the same letter are not significantly different $(P>0.05)$. 
0.8 units, respectively. For the $15-30 \mathrm{~cm}$ depth, a drop in values from 2006 to 2007 were 15.8 and $168 \%$ respectively for PR1 and PR3.

Effect of treatment on exchangeable potassium

More than $80 \%$ of values recorded were below the deficiency threshold of $0.15 \mathrm{cmol} / \mathrm{kg}$ (IRHO, 1960) by 2006 (Table 9). There were fluctuations in the values of exchangeable po- tassium from 2004 to 2007 in the $15-30 \mathrm{~cm}$ depth. However, values increased gradually from 2004 to 2007 in the $0-15 \mathrm{~cm}$ soil depth.

\section{Effect of treatment on soil exchangeable} acidity

Table 10 shows soil exchangeable acidity as influenced by treatments. Differences that were recorded during the test period were not significant in both soil depths. Soil exchangeable

Table 9: Effect of treatment on dynamics of soil exchangeable potassium (cmol/ $\mathrm{kg}$ ) from 2004 to 2007

\begin{tabular}{|c|c|c|c|c|}
\hline Treatment & 2004 & 2005 & 2006 & 2007 \\
\hline \multicolumn{5}{|c|}{$0-15 \mathrm{~cm}$ soil depth } \\
\hline TSP & $0.03 a$ & $0.02 \mathrm{a}$ & $0.03 \mathrm{a}$ & $0.93 \mathrm{a}$ \\
\hline PR1 & $0.01 \mathrm{a}$ & $0.01 \mathrm{a}$ & $0.02 \mathrm{a}$ & $1.15 \mathrm{a}$ \\
\hline PR2 & $0.02 \mathrm{a}$ & $0.02 \mathrm{a}$ & $0.03 \mathrm{a}$ & $0.98 \mathrm{a}$ \\
\hline PR3 & $0.02 \mathrm{a}$ & $0.02 \mathrm{a}$ & $0.03 \mathrm{a}$ & $0.93 \mathrm{a}$ \\
\hline $\mathrm{CV}(\%)$ & 76.50 & 71.4 & 57.00 & 56.30 \\
\hline $\operatorname{LSD}(5 \%)$ & 0.03 & 0.03 & 0.03 & 1.12 \\
\hline \multicolumn{5}{|c|}{$15-30 \mathrm{~cm}$ soil depth } \\
\hline TSP & $0.02 b c$ & $0.02 \mathrm{a}$ & $0.02 b c$ & $0.11 \mathrm{a}$ \\
\hline PR1 & $0.01 \mathrm{c}$ & $0.01 \mathrm{c}$ & $0.01 \mathrm{c}$ & $0.10 \mathrm{a}$ \\
\hline PR2 & $0.34 \mathrm{a}$ & $0.34 \mathrm{a}$ & $0.02 b c$ & $0.10 \mathrm{a}$ \\
\hline PR3 & $0.01 \mathrm{a}$ & $0.01 \mathrm{c}$ & $0.20 \mathrm{a}$ & $0.07 \mathrm{a}$ \\
\hline $\mathrm{CV}(\%)$ & 86.00 & 286.40 & 42.3 & 46.00 \\
\hline $\operatorname{LSD}(5 \%)$ & 0.03 & 0.55 & 0.010 & 0.09 \\
\hline
\end{tabular}

Means followed by the same letter are not significantly different $(P>0.05)$.

Table 10: Effect of treatment on dynamics of soil exchangeable acidity $(\mathrm{A}+\mathrm{H})$ (cmol/kg) 2004 to 2007

\begin{tabular}{lcccc}
\hline Treatment & $\mathbf{2 0 0 4}$ & $\mathbf{2 0 0 5}$ & $\mathbf{2 0 0 6}$ & $\mathbf{2 0 0 7}$ \\
\hline & $\mathbf{0 - 1 5 c m}$ soil depth & & \\
TSP & $0.26 \mathrm{a}$ & $0.66 \mathrm{a}$ & $1.07 \mathrm{a}$ & $0.21 \mathrm{a}$ \\
PR1 & $0.26 \mathrm{a}$ & $0.32 \mathrm{a}$ & $0.39 \mathrm{a}$ & $0.26 \mathrm{a}$ \\
PR2 & $0.24 \mathrm{a}$ & $0.28 \mathrm{a}$ & $0.31 \mathrm{a}$ & $0.20 \mathrm{a}$ \\
PR3 & $0.28 \mathrm{a}$ & $0.34 \mathrm{a}$ & $0.41 \mathrm{a}$ & $0.28 \mathrm{a}$ \\
CV (\%) & 6.60 & 55.80 & 82.90 & 23.60 \\
LSD (5\%) & 0.03 & 0.44 & 0.91 & 0.11 \\
& $\mathbf{1 5}-\mathbf{3 0 c m}$ soil depth & & \\
TSP & $1.07 \mathrm{a}$ & $1.20 \mathrm{a}$ & $1.35 \mathrm{a}$ & $0.18 \mathrm{~b}$ \\
PR1 & $1.08 \mathrm{a}$ & $0.73 \mathrm{a}$ & $0.39 \mathrm{a}$ & $0.23 \mathrm{a}$ \\
PR2 & $1.26 \mathrm{a}$ & $0.75 \mathrm{a}$ & $0.23 \mathrm{a}$ & $0.20 \mathrm{a}$ \\
PR3 & $1.19 \mathrm{a}$ & $0.82 \mathrm{a}$ & $0.46 \mathrm{a}$ & $0.28 \mathrm{a}$ \\
CV (\%) & 13.70 & 39.20 & 112.0 & 21.30 \\
LSD (5\%) & 0.31 & 0.68 & 1.35 & 0.09 \\
\hline
\end{tabular}

Means followed by the same letter are not significantly different $(P>0.05)$. 


\section{Danso et al.}

acidity values ranged from 0.20 to $1.07 \mathrm{cmol} /$ $\mathrm{kg}$ and 0.18 to $1.35 \mathrm{cmol} / \mathrm{kg}$ for $0-15 \mathrm{~cm}$ and 15 $-30 \mathrm{~cm}$ soil depth respectively. Values that were recorded in 2004 for both soil depths were higher than values obtained at the end of the study (2007).

Effect of treatment on Effective Cation Exchange Capacity (ECEC)

Table shows effective cation exchange capacity (ECEC) as influenced by treatments. Values of ECEC decreased with depth. The highest ECEC of $12.6 \mathrm{cmol} / \mathrm{kg}$ occurred in PR2 at a depth $0-15 \mathrm{~cm}$ in the year 2006 with the lowest of $3.23 \mathrm{cmol} / \mathrm{kg}$ recorded by PR1 in 2004 at a depth of $0-15 \mathrm{~cm}$. A gradual decrease in ECEC from 2004 to 2007 in the $0-15 \mathrm{~cm}$ for TSP treatment (control) was recorded. By the end of the study individual PR treatments recorded higher values than TSP (control) in both soil depths.

Effect of treatment on leaf area development Figure 1 shows the effect of treatment on leaf area. Treatments did not significantly affect leaf area throughout the experimental period. Over the period, the highest and the lowest leaf area values of 8.52 and $6.45 \mathrm{~m}^{2}$ were recorded by treatment PR2 and TSP respectively. Mean leaf area per palm in 2004 was $6.84 \mathrm{~m}^{2}$. This increased to $9.0,7.1$ and $14.2 \mathrm{~m}^{2}$ in 2005,2006 and 2007 respectively.

Effect of treatment on oil palm yield (t/ha)

The yield of oil palm defined as the product of the number of bunches and weight of bunches per ha from 2004 to 2007 is shown in Table 12 . Fresh fruit bunches per ha was not significantly different among treatments except in 2006. The highest fresh fruit bunches per ha of 18.88 t/ha was recorded in 2006 for PR2 whilst the lowest of $9.92 \mathrm{t} /$ ha was recorded in 2007 for TSP (control). In calculating the relative yield increase (R1) of PR treated plots, TSP treated plots were used as standard treatment. The RI during the early stages of the trial (2004) for PR1, PR2 and PR3 were 6.0, 2.0 and $25.0 \%$ respectively. By 2007 the values had increased to 17.5 and $28.9 \%$ for PR1 and PR2 respectively with PR3 recording a decreased value of $13.1 \%$. For the years 2004 and 2007, RI were in the order of PR3 $>$ PR1 $>$ PR2 and PR2 $>$ PR1 $>$ PR3 respectively

Table 11: Effect of treatment on dynamics of Effective Cation Exchange Capacity (cmol/kg) from 2004 to 2007

\begin{tabular}{lcccc}
\hline Treatment & $\mathbf{2 0 0 4}$ & $\mathbf{2 0 0 5}$ & $\mathbf{2 0 0 6}$ & $\mathbf{2 0 0 7}$ \\
\hline \multicolumn{4}{c}{$\mathbf{0 - 1 5} \mathbf{~ c m ~ s o i l ~ d e p t h ~}$} \\
TSP & $4.94 \mathrm{a}$ & $4.74 \mathrm{a}$ & $4.60 \mathrm{a}$ & $4.35 \mathrm{a}$ \\
PR1 & $4.99 \mathrm{a}$ & $4.75 \mathrm{a}$ & $4.50 \mathrm{a}$ & $5.50 \mathrm{a}$ \\
PR2 & $4.56 \mathrm{~b}$ & $8.69 \mathrm{a}$ & $12.60 \mathrm{a}$ & $7.52 \mathrm{a}$ \\
PR3 & $4.46 \mathrm{c}$ & $5.43 \mathrm{a}$ & $6.40 \mathrm{a}$ & $6.04 \mathrm{a}$ \\
CV (\%) & 3.50 & 50.20 & 82.90 & 49.50 \\
LSD (5\%) & 0.33 & 5.91 & 11.63 & 5.78 \\
& $\mathbf{1 5 - 3 0} \mathbf{~ c m ~ s o i l ~ d e p t h ~}$ & & \\
TSP & $3.52 \mathrm{a}$ & $3.90 \mathrm{a}$ & $4.28 \mathrm{a}$ & $4.06 \mathrm{a}$ \\
PR1 & $3.23 \mathrm{a}$ & $3.51 \mathrm{a}$ & $3.79 \mathrm{a}$ & $4.31 \mathrm{a}$ \\
PR2 & $3.26 \mathrm{ab}$ & $5.42 \mathrm{a}$ & $7.59 \mathrm{a}$ & $6.05 \mathrm{a}$ \\
PR3 & $3.43 \mathrm{ab}$ & $4.70 \mathrm{a}$ & $5.97 \mathrm{a}$ & $3.21 \mathrm{a}$ \\
CV (\%) & 3.60 & 39.80 & 63.3 & 49.50 \\
LSD (5\%) & 0.24 & 3.48 & 6.84 & 4.35 \\
\hline
\end{tabular}

Means followed by same letter are not significantly different $(P>0.05)$.

Journal of Science and Technology @ KNUST April 2010 


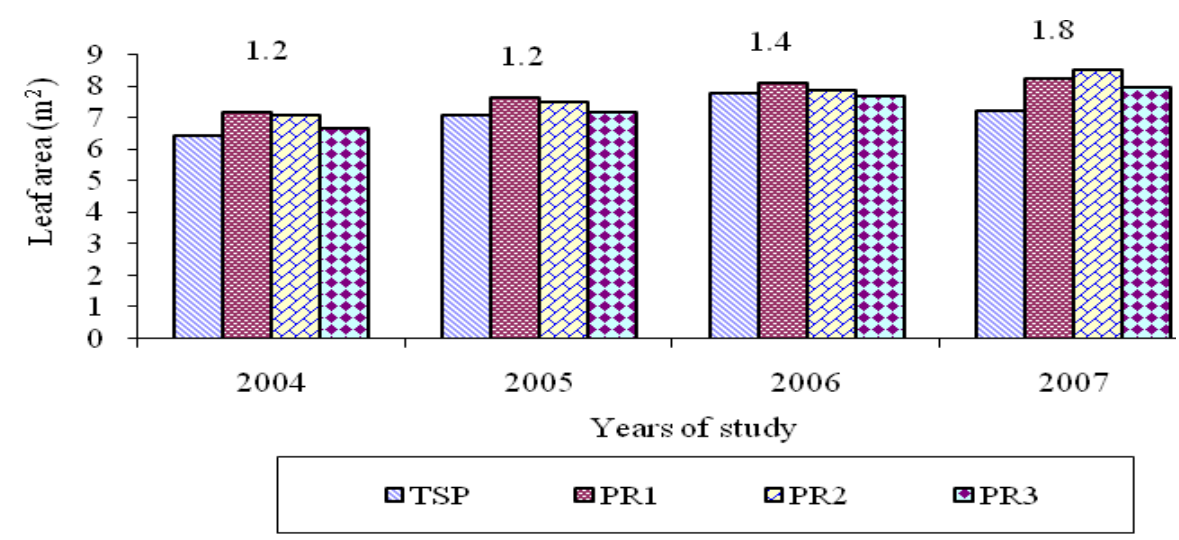

Fig. 1: Effect of treatmentls of palm leaf area

Figures on bars represent lsd values. Where Lsd $=p<0.05$

\section{DISCUSSION}

Pre-experimental soil characteristics

The low $\mathrm{pH}$ values of soil were similar to those reported for some Ghanaian soils by Adu and Tenadu (1979). Strong leaching of the basic cations out of the top soil contributed to low $\mathrm{pH}$ values. It is expected that this factor will affect the dynamics of all nutrients and especially phosphate because the available $\mathrm{P}$ depends to a large extent on interactions with constituents carrying a variable charge (Quang et al., 1996).

The very low organic carbon content and low exchangeable bases particularly calcium re- flected the generally highly weathered soils in the humid rainforest agro-ecological zone of the country (Owusu-Bennoah et al., 2000). This property of the soil is attributed mainly to the excessive leaching of the soils caused by high rainfall associated with oil palm growing areas in Ghana and constant plant nutrient uptake by the crop. The low ECEC values could be attributed to the low organic matter and to the fact that the clay fraction is dominated by low activity clays (kaolinite) (Owusu-Bennoah et al., 1996). The high build up of available $\mathrm{K}$ in the $15-30 \mathrm{~cm}$ depth could be attributed to

Table 12: Effect of treatments on fresh fruit bunches and relative yield increase (RI) from 2004 to 2007

\begin{tabular}{lrrrrrrrr}
\hline \multirow{2}{*}{ Treatment } & \multicolumn{4}{c}{ Yield (t/ha) } & \multicolumn{4}{c}{ R1\% } \\
& $\mathbf{2 0 0 4}$ & $\mathbf{2 0 0 5}$ & $\mathbf{2 0 0 6}$ & $\mathbf{2 0 0 7}$ & $\mathbf{2 0 0 4}$ & $\mathbf{2 0 0 5}$ & $\mathbf{2 0 0 6}$ & $\mathbf{2 0 0 7}$ \\
\hline TSP & 13.5 & 13.53 & 16.76 & 9.93 & - & - & - & - \\
PR1 & 16.0 & 14.70 & 18.61 & 11.67 & 6.0 & 8.6 & 1.1 & 17.5 \\
PR2 & 13.8 & 17.30 & 18.88 & 12.80 & 2.0 & 27.8 & 12.6 & 28.9 \\
PR3 & 16.9 & 12.6 & 17.56 & 11.23 & 25.0 & $6.0 *$ & 4.8 & 13.1 \\
CV (\%) & 25.8 & 17.1 & 1.6 & 23.9 & & & & \\
LSD (5\%) & N.S & N.S & 0.58 & N.S & & & & \\
\hline
\end{tabular}

* indicates relative decrease in yield (t/ha) as compared to TSP in 2005 


\section{Danso et al.}

movement of $\mathrm{K}$ minerals due to leaching. The available $P$ content of 0.8 and $0.2 \mathrm{mg} / \mathrm{kg}$ for the depths $0-15$ and $15-30 \mathrm{~cm}$ depth respectively indicated that the soil was extremely low in P. According to Hartley (1988), the threshold deficiency for $P$ is $10 \mathrm{mg} / \mathrm{kg}$. This could be attributed to the advanced stage of weathering of the parent rocks which lacked primary weatherable minerals necessary for nutrient recharge (Charreau, 1974).

Although all inorganic $\mathrm{P}$ cannot be considered sorbed $\mathrm{P}$, these findings together with the Bray $\mathrm{P}$ results strongly suggested deficiency of $\mathrm{P}$ in the soil and hence, the need for P fertilizer application.

\section{Soil nutrient dynamics}

Soil nutrients were concentrated in the top 0-15 $\mathrm{cm}$ and tended to decrease with depth, suggesting that a greater part of these nutrients may be associated with organic matter present in the top soil (Aweto, 1988). While superphosphate application generally leads to a reduction of soil organic matter in the top soil, PR applied with other inorganic fertilizers resulted in significant increases in total organic $C$, available$\mathrm{P}$, soil respiration, microbial biomass and enzyme activities (Melero et al., 2006). The results of this study showed that, PR treatments in the $0-15 \mathrm{~cm}$ depth were comparatively higher in organic matter content and available$\mathrm{P}$ than TSP treatment of the same depth. The reduction in organic matter after 2006 for both two soil depths in treatment PR2 could be attributed to mineralization. This is consistent with reports by Azeez et al. (2007) that mineralization of organic matter takes place during cropping season after fertilizer application. The maintenance of high organic matter levels in the top soil is therefore very important for sustainable soil fertility and for enhancing oil palm productivity.

The $\mathrm{pH}$ of the soil at the start of the experiment was extremely acid ( $\mathrm{pH} 4.42$ and 4.13 for the 0 15 and $15-30 \mathrm{~cm}$ soil depths respectively). The $\mathrm{RP}$ treated plots reached a suitable range of $\mathrm{pH}$ of 5.0-5.5 (strongly acidic) for optimum oil palm nutrient uptake except PR3 in soil depth 0 $-15 \mathrm{~cm}$. These results on $\mathrm{pH}$ confirm the findings by Zin et al. (2005) that PR fertilizers have a higher content of $\mathrm{Ca}$ (ranging from 24-33\%) which could increase soil $\mathrm{pH}$ and effective cation exchange capacity (ECEC) and positively affect yield of oil palm. The high acidity recorded in TSP treated plots compared to the PR plots at the end of the experiment was due to the low

content of $\mathrm{Ca}$ in TSP and the remnants of phosphoric acid used in the manufacture process of the triple superphosphate fertilizers.

The available P (Bray P) at the start of the experiment was low and agreed with that reported by Ankomah et al. (1995) in similar Ghanaian soils. Thomas and Peaslea (1973) suggested that most soils containing extractable P of less than $15 \mathrm{mg} / \mathrm{kg}$ as determined by Bray 1 method could be defined as being deficient in available $\mathrm{P}$ for optimal plant growth. These are similar to the values suggested by Olson and Engelsted (1972) and Menon et al. (1995). By the end of the experiment the highest available $\mathrm{P}$ was still below the medium range of $10-20 \mathrm{mg} / \mathrm{kg}$ (Hartley, 1988). The results obtained for this study confirmed the findings of Pieri (1986) that $\mathrm{P}$ is one of the most limiting nutrients for crop growth in tropical soils. Available $\mathrm{P}$ reported in PR treated plots were promising than values obtained for TSP treated plots. According to Sale and Mokwunye (1993), PR applied to P-deficient acid soils encounted in humid forest zone dissolve slowly to sustain soil levels and plant growth. Allen et al. (1995) also observed slow release of $\mathrm{P}$ to the soil by PR. As a result, Adam et al. (1987) suggested that PR should be used on perennial crops rather than annual crops and research must focus on treating PR to increase solubility. Studies by Hammond et al. (1986) and Chien and Menon (1995) have shown that partial acidulation of PR (PAPR) is one way to increase water solubility and agronomic effectiveness of PRs at a lower cost than would be required to manufacture the conventional, fully acidulated fertilizers as Single Superphosphate or TSP. The low 
$P$ values recorded in the $15-30 \mathrm{~cm}$ could possibly be due to P-fixation by aluminosilicates, since clay generally accumulates in the subsoil of tropical soils (Obeng, 1990).

The status of $\mathrm{N}$ was relatively low, both at the beginning and at the end of the study as well. Values of $\mathrm{N}$ decreased with depth and almost all the $\mathrm{N}$ values recorded were below the medium range of 0.1-0.2 \% (Hartley, 1988). Continual supply of $\mathrm{N}$ is necessary since it is very difficult to build large $\mathrm{N}$ reserves.

Lower soil $\mathrm{P}$ levels as experienced in this study, could prevent the uptake and the use of available potassium (Hartley, 1988). This and the fact that $\mathrm{K}$ was applied annually might have given rise to the general increase in available $\mathrm{K}$ as experienced from 2006 to 2007 in this study. This could also be due to the replenishment from the potassium pool at the end of the experiment. The build up of available $\mathrm{K}$ in the 15 $30 \mathrm{~cm}$ soil depth in 2007 may indicate the movement of $\mathrm{K}$ fertilizers due to leaching. This observation supports that of Weerasinghe and Premalal (2002) who observed a build up of K in deeper soil layers indicating the movement of $\mathrm{K}$ fertilizers due to leaching.

The low $\mathrm{pH}$ in TSP treated plots resulted in a smaller proportion of exchangeable $\mathrm{Ca}$ and $\mathrm{Mg}$ (Roy et al., 2006). According to Havlin et al. (1999), the availability of $\mathrm{K}^{+}$is generally dependent on its concentration relative to that of $\mathrm{Ca}^{2+}$ and $\mathrm{Mg}^{2+}$. Thus, $\mathrm{K}^{+}$uptake increases as concentrations of $\mathrm{Ca}^{2+}$ and $\mathrm{Mg}^{2+}$ decline in the soil solution and vice versa. This may explain the yearly variation in almost all the soil nutrients analyzed.

In a study of soil nutrient dynamics, Roy et al. (2006) observed that the content of available nutrients and their degree of availability and accessibility was not a static condition but an ever-changing and very dynamic process due to the various inorganic and biochemical processes that take place in soils.

Growth, development and yield of oil palm It has been found that there is superior residual effect of PR compared to water soluble P (TSP) more especially in acidic soils (Sale and Mokwunye, 1993). Bolan et al. (1990) noted that incorporation of PR into the soil ensured a sustainable supply of $\mathrm{P}$ over a long period and also created a high rooting density for better nutrient exploration. This resulted in increased yield of $16.9 \%$ (PR2) over TSP treated plots. Research done on PR in the United States provides an idea of the duration of the effect from residual $\mathrm{P}$ on a soil (Tisdale et al., 1985). They provided data to show that irrespective of the rate of $\mathrm{P}$, there was a residual effectiveness up to the seventh crop and response to initial and residual $P$ increased with increasing rates. A similar observation was made in this trial where single application rate of $1428 \mathrm{~kg} P R+222 \mathrm{~kg}$ AS $+296 \mathrm{~kg}$ of MOP once in 5 years (PR2) gave promising results both morphologically and reproductively. Similarly, in Brazil, a single application of PR per ha of land deficient of $P$ gave 100 percent yield increase in oil palm over a period of 6 years (Hartley, 1988).

Decrease in yield in TSP plots (control) could be attributed to very acidic conditions of soil. In 2007, PR treated plots (PR2) recorded a moderately acidic values of $\mathrm{pH}$ which made the crop better adapted for effective nutrient uptake resulting in good growth, development and yield of oil palm. Jacquemard (1998) observed that the oil palm can cope with acidic soils but is better adapted near to neutral soil $\mathrm{pH}$ values.

The overall response of oil palm to P fertilizers showed a higher fresh fruit bunch yield and development where PR was applied to the soil and was statistically better than the fresh fruit bunches yield produced by TSP (Table 12 and Fig. 1). This is in agreement with Sale and Mokyunye (1993) that, PR applied to the soil (such as P-deficient acidic Ferralsols encounted in the humid forest zone), dissolves readily to sustain plant growth.

\section{CONCLUSION}

The physico-chemical properties of the soil before the application of treatments indicated that, the soil is highly acidic, low in available phosphorus and low in organic matter all lead- 


\section{Danso et al.}

ing to low effective CEC. This could be attributed to excessive leaching and constant nutrient uptake by oil palm trees. The use of PR positively influences chemical properties of the soil especially increasing exchangeable cations and available $\mathrm{P}$ in the soil. Application of $\mathrm{PR}$ at the rate of $1428 \mathrm{~kg}$ per ha once in every 5 years gave the highest yield. The study has clearly shown that agronomically it is sound to use PR under oil palm.

\section{ACKNOWLEDGEMENT}

The authors express their profound gratitude to the staff of Agronomy Division, CSIR - OPRI who helped to execute the study and collect data. The efforts of Dr. G.K. Yawson and Dr. S.K Dery are also acknowledged for their constructive criticism. This paper is published with the permission of the Director, CSIR - OPRI.

\section{REFERENCES}

Adams, F., Khasawneh, F.E. and Henao, J. (1987). Effects of combination of triple super phosphate and reactive rock phosphate on yield and phosphorus uptake by corn. Soil Science Society of America Journal 51:1656-1658.

Adu, S.V. and Tenadu, D.O. (1979). Soils of the Proposed Enchi Rubber Project Area near Gyema, Western Region. Tech. Report No. 121, S.R.I., C.S.I.R. KwadasoKumasi, Ghana.

Allen, E., Ming, D., Hossner, L., and Herninger, D. (1995). Modeling transport kinetics in clinoplilolite-phosphate system. Soil Science Society of America Journal 59:248 -255 .

Ankomah, A.B., Zapata, F.Z., Danso, S.K.A., and Axmann, H. (1995). Cowpea varietal differences in uptake of phosphate rocks in a low ultisols. Fert. Res. 41:219-225.

Asamoah, T.E.O. and Nuertey, B.N. (2005). Physico-chemical characteristics and suitably of soils of areas climatically suitable for optimal oil palm production in Ghana. Ghana Jnl. Agric. NARS 1: 66-27.
Aweto, A.O. (1988). Effects of shifting cultivation on a tropical rainforest soil in Southwestern Nigeria. Turriabala (IICA) $38: 19-22$.

Azeez, J.O., Adetunji, M.T. and Adebusuyi, B. (2007). Effects of residue burning and fertilizer application on soil nutrient dynamics and dry grain yield of maize in an Afisol in Nigeria. Nigeria Jnl. of Soil Science 31: 71 $-80$

Bolan, N.S., White, R.E., and Hedley, M.J. (1990). A review of the use of phosphate rocks as fertilizers for direct application in Australia and New Zealand. Aust. J. Exp. Agric 30: $297-313$.

Bouyoucos, G.J. (1962). Hydrometer method improved for making particle size analysis of soils. Agronomy Journal 54: 464 - 465.

Bray, R.H. and Kurtz, L.T. (1945). Determination of total, organic and available forms of phosphorus in soil. Soil Science 599: 39 45.

Charreau, C. (1974). Soil of tropical dry and dry-wet climatic areas of West Africa and their use and management. Agronomy Mimeo 74 - 26. Department of Agronomy, Cornell University, Ithaca, N.Y.

Chien, S.H. and Menon, R.G. (1995). Factors affecting the agronomic effectiveness of phosphate rock for direct application. Fert. Res., 41: 227 - 234.

CSIR-OPRI. (2007). Commissioned annual report by Council for Scientific and Industrial Research of Oil Palm Research Institute, Kusi, Ghana.

Dedzoe, C.D., Antwi, B.O. and Tetteh, F.M. (2004). Detailed soil studies for exportable pineapple production at Bawjiase, Central Region. The case of UNIFRUIT LTD SRI Tech. Report No. 237.

FAO, (1990). Soil Map of the World- Revised Lengend, $4^{\text {th }}$ Draft. FAO. Rome.Fertilizer research 36: $141-150$.

Foster, D.R., Motzkin, G. and Slater, B. (1998). 
Land-use history as long term broad scale disturbance: regional forest dynamics in Central New England. Ecosystems 1: 96119.

GENSTAT (1997). GENSTAT 5, Release 3.2 Lawes Agricultural Trust, Rothamsted. Experimental Station UK.

Griffiths, W. and Fairhurst, T. H. (2002). Implementation of Best Management practices in an oil palm rehabilitation project in South Sumatra Indonesia. Better crops International Vol. 17 No. 1.

Hammond, L.L., Chien, S.H. and Easterwood, G.W. (1986). Agronomic effectiveness of Bayovar phosphate rock in soil with induced phosphorus retention. Soil Science Society of America Journal 50: 1601 1606.

Hartley, C.W.S. (1988). The Oil Palm. (Tropical Agriculture Series) $3^{\text {rd }}$ ed. Longman Scientific and Technical, Harlow. Pp. 761.

Havlin.J.L., Beaton, J.D., Tisdale, S.L. and Nelson, W.L. (1999). Soil fertility and fertilizers: An introduction to nutrient management $\left(6^{\text {th }}\right.$ edition). Upper Saddle River, New Jessey: Printice-Hall. Pp. 1-94

Healed, W.R. (1965). Calcium and Magnessium. In: 'method of soil analysis' Part 2, Agronomy No. 9; pp. 999-10110 Black CA (Ed) Am Soc. of Agron., Madison, Winsconsin.

IRHO (1960). Institute de Researches pour les Huiles et Oleagineux, Rapports Annueles 1960.

IRHO (1974). Rapport d'activites, 1972 - 73. document 1138, Paris.

Jacquemard, J.C. (1998). Oil Palm. The Tropical Agriculture. Macmillan 144 pp.

Melero, S., Poras J.C., Herencia J.F. and Madejon, E. (2006). Chemical and biochemical propertiesin a silty loam soil under conventional and organic management.
Menon, R.G., Chien S.H and Hellums. D.T. (1995). Fe and A1-oxide influence on agronomic effectiveness of modified phosphate rock. Soil Science Society of America Journal 59: 1762 - 1767.

Nelson, D. W. and Sommers, L.W. (1982). Total carbon, organic carbon and organic matter, In: Page, A.L., R.H. Miller, and D.R. Keeney. (eds.). Methods of Soil Analysis. 2. Chemical and Microbiological Properties. Agronomy 9: 301-312.

Nuertey, B.N. (1999). Studies on oil palm based cropping systems in Ghana. Ph.D Thesis. University of Ghana, Crop Science Department.

Obeng, H.B. (1990). Fertilizer requirement and use in Ghana. Report submitted to the Govt of Ghana. Tropical Agric. Dev. Consultancy, Accra Ghana.

Olsen, S.R., and Engeltad, O.P. (1972) Soil phosphorus and sulphur. In: Soils of the Humid Tropics. National Academy of Sciences, Washington, D.C. pp 82-97.

Owusu-Bennoah, E., Czilas, C., Hansen, H.C.B. and Borggaard, O.K. (1996). Phosphate sorption in relation to aluminium and iron oxides of Oxisols from Ghana. Communications in Soil Science and Plant Analysis 37:94-105

Owusu-Bennoah, E., Fardeau, J.C. and Zapata, F. (2000). Evaluation of biovailable phosphorus in some acid soils of Ghana using ${ }^{32} \mathrm{P}$ isotopic exchange method Ghana Jnl. Agric. Sci. 33: 139-146.

Pieri, C. (1986). Fertilization des cultures vivrieres et fertilite des sols en agriculture paysanne

Quang Vo Di Thai Vu, C., Linh, T.T.T and Dutey, K. (1996). Phosphate sorption in soils.

Roy R.N., Finck, A., Blair, G.J. and Tandon, H.L.S. (2006). Plant nutrition for food security: A guide for integrated nutrient management. FAO Fertilizer and Plant Nutrition Bulletin 16:1-346. 


\section{Danso et al.}

Sale, P.W.G. and Mokwunye, A.U. (1993). Use of phosphate rocks in the tropics. Fert. Res.35: 33 - 45 .

Tetteh, F.M. and Dedzoe, C.D. (2004). Soil quality assessment of selected farms and lands under rehabilitation within Bogoso Gold Ltd. (BGL) concession, Western Region. SRI Tech. Report No. 24.

Tetteh, F.M., Dedzoe, C.D. and Oppong. J. (2002). The impact of oil palm plantation development on soil chemical properties. The case of Benso ail palm plantation Ltd. SRI Tech. Report No. 214.

Thomas, G.W., and Peaselea. D.E., (1973). Testing soils for P. In: Soil Testing and Plant Analysis. L.M. Walsh and J.D. Beaton (eds.). Soil Science Society of America. Madison W.S. pp. 115-132.

Tisdale, S.M., Nelson, W.L. and Beaton, J.D. (1985). Soil fertility and fertilizers, fourth edition. Macmillan Publishing Company, New York. Pp 189 - 236.
USDA. (1991). Year Book of Agriculture. Macmillan Publishing Company, Washington. Pp 10-12.

Weerasinghe, P. and Premalal N.H.R. (2002). Influence of potassium fertilization on growth and yield of embul banana grown in Rhodudalfs under irrigated conditions. Annals of the Sri Lanka Department of Agriculture. 4:109-117.

Yeates, J.S. (1993). Developing alternatives to phosphate fertilizers of high water solubility. Fertilizer research 36:141-150.

Zin, Z.Z., Zulkifli, H. Tarmizi, A.M., Hamadan, A.B., Khalid, H. and Raja, Z.R.O. (2005). Rock phosphate fertilizers recommended for young oil palm planted on inland soils. MPOB information series. ISSN 1511-7871. 